PAEDAGOGIA ChristianA

2/24 (2009) - ISSN 1505-6872

Anna Szylar*

Tarnobrzeg

\title{
Z dziejów szkoły żeńskiej w Staniątkach w 2. polowie XIX wieku
}

Głównym celem niniejszego szkicu jest próba przedstawienia organizacji życia uczennic w pensjonacie dla dziewcząt prowadzonym przez Benedyktynki w Staniątkach w okresie od wprowadzenia autonomii w Galicji do schyłku XIX wieku. Istniejąca tam szkoła miała długie tradycje, potwierdzają ten fakt wizytacje biskupie z końca XVI wieku, mówiące o pannach świeckich oddawanych „na czwiczenie” do klasztoru. I nie chodzi tu tylko o kandydatki do zakonu, ponieważ te, po pobycie w szkole świeckiej, miały prawo przyjęcia habitu i przechodziły do odrębnej szkoły dla nowicjuszek. Pozostałe wychowanki po zakończeniu edukacji wracały do domów rodzinnych. Podobny charakter organizacyjny szkoły utrzymywał się do 1784 roku, kiedy to po jej reorganizacji w duchu zgodnym z polityką oświatową Austrii, w granicach której znalazł się klasztor po pierwszym rozbiorze, utworzono tzw. szkołę „,normalną”, podlegającą władzom świeckim. Byt klasztoru od tego czasu do wprowadzenia autonomii w Galicji w 1866 roku uzależniony był od akceptacji działającej przy nim szkoły. W 1869 roku szkoła utraciła prawa publiczne i wcale nie starano się o ich odzyskanie, ponieważ umożliwiło to ściślejsze realizowanie misji duchowej klasztoru. Istnienie szkoły zależało od napływu uczennic, a ich oczekiwania co do nauki były w dalszym ciagu wysokie, wiele $\mathrm{z}$ nich dążyło do przygotowania się tutaj do dalszej edukacji. Przez cały ten czas szkoła się rozwijała, w 1870 roku powstała klasa szósta, cztery lata później siódma, a w 1884 roku ósma. Wysoki poziom nauczania potwierdzały wizytacje, a władze oświatowe uznawały szkołę w Staniątkach na równi ze szkołami mającymi prawa państwowe ${ }^{1}$.

* Dr Anna Szylar, zatrudniona w Instytucie Pedagogiki Państwowej Wyższej Szkoły Zawodowej im. prof. Stanisława Tarnowskiego w Tarnobrzegu.

${ }^{1}$ Por. B. Krasnowolski, Historia klasztoru benedyktynek w Staniatkach, Kraków 1999, s. 68, $115-116,160$. 
Nadzór nad szkołą miała zakonnica pełniąca urząd prefekty. W interesującym okresie były nimi kolejno: Elżbieta Porębska (1863-1888), Leontyna Kämpf (1889-1894) i Marianna Paul (1894-1908)². Dużym prestiżem cieszyła się posada „katechety dyrygującego", będąca od 1870 roku połączeniem stanowiska katechety i dyrektora szkoły. Nauczycielkami były przeważnie zakonnice nazywane mistrzyniami, a do prowadzenia lekcji z języków obcych, muzyki czy tańca zatrudniano guwernantki.

Do szkoły uczęszczały dziewczęta mieszkające w Staniątkach lub okolicy, ale większość stanowiły panny z odległych miejscowości, mieszkające w pensjonacie nazywanym też konwiktem. Organizację szkoły i internatu określały wewnętrzne regulaminy, których kilka zachowało się w archiwum klasztornym ${ }^{3}$. Datowane są one na rok 1880, 1892 oraz 2. połowę XIX wieku i stanowią wyśmienity materiał porównawczy do analizy funkcjonowania pensji klasztornej w świetle własnych uregulowań organizacyjnych. Dopełnienie stanowi kronika konwiktu rozpoczynająca się w 1888 roku z fragmentami tekstu odnoszącymi się też do czasów wcześniejszych i doprowadzona do 1897 roku$^{4}$. Na jej podstawie można zweryfikować obowiązujące przepisy z realiami życia uczennic, ich zachowanie, przestrzeganie zarządzeń oraz radości i trudy życia szkolnego widziane oczami autorki kroniki, mistrzyni Krystyny Brunickiej. Nie jest możliwe pełne wykorzystanie wszystkich, niezwykle ciekawych informacji, niemniej przytoczone poniżej dane pozwalają na omówienie zasadniczych kwestii.

Uczennica przybywająca do konwiktu powinna być zaopatrzona w niezbędną odzież oraz posiadać pieniądze na opłacenie pobytu. Spis z 1866 roku obejmuje wykaz wyposażenia, znajduje się w nim 12 koszul, 6 prześcieradeł, 4 ręczniki, 6 poszewek, obrus i 4 serwety. Liczba sukien zależała od woli rodziców, miały być one skromne, a wśród nich koniecznie powinna znajdować się sukienka koloru białego. Inny, nieco późniejszy spis, bardziej uszczegóławiał katalog potrzebnej odzieży. Odnotowano w nim 6 sukien, 4 spódniczki i do nich tyle samo dzien-

${ }^{2}$ Archiwum Benedyktynek w Staniątkach (dalej: ABSt.), rps Regestr sióstr XVI - XIX w., sygn. 361, s. 148-149, 165, 167-168. B. Krasnowolski podaje (s. 302), że prefektą po E. Porębskiej została K. Brunicka, jednak wydaje się, że pomimo jej przeniesienia się do izby prefekty w $1888 \mathrm{r}$. sprawowała ona tylko urząd mistrzyni i miała zlecone wykonywanie części zadań przypadających prefekcie, pozostałe zadania wykonywała wiceprefekta, którą była wtedy L. Kämpf. W 1889 roku siostra Kämpf podpisywała się już jako prefekta pod świadectwami uczennic, natomiast K. Brunicka w dalszym ciągu pełniła funkcję mistrzyni tzw. dolnej, do jej obowiązków należało zarządzanie konwiktem, sługami, prowadzenie korespondencji uczennic. (Por. ABSt., sygn. 1388, s. 3, 12, X; sygn. 361, s. 173-174).

3 ABSt., rps Ustawy dla pp. konwiktorek w Staniątkach 1892, sygn. 1221; rps Regulamin dla uczennic i wychowanek szkoły w Staniątkach XIX w., sygn. 1222, niep.; rps sygn. 1223 podzielony jest na dwie części posiadające odrębne tytuły, cz. I: Ustawy i przepisy zakładu naukowo-wychowawczego PP. Benedyktynek pod wezwaniem św. Scholastyki w Staniątkach (II poł. XIX w.), cz. II: Ustawy dla konwiktorek szkoły wyższej żeńskiej, Staniątki 1880, ponieważ tylko druga część posiada paginację, w przypisach sygnatura bez paginacji odnosi się do cz. I, a z paginacją do cz. II.

${ }^{4}$ ABSt., rps Kronika konwiktu staniąteckiego od roku 1888, sygn. 1388. 
nych bluzek z długimi rękawami, 12 par pończoch i 6 par butów, były wśród nich buciki, trzewiki i barlacze na zimę $e^{5}$ Na procesjach, uroczystościach kościelnych, podczas egzaminów, imienin ksieni i przy innych ważnych okazjach uczennice występowały w brązowych mundurkach, jednak w spisie wyposażenia takowe nie figurują. Być może zaopatrywały się w nie dopiero po jakimś okresie pobytu na pensji ${ }^{6}$. Na zimę każda panna powinna mieć 2 ciepłe kubraki, płaszczyk i 2 małe chustki na szyję. Wymagano też, aby każda pensjonarka przywoziła ze sobą łóżko z materacem oraz pościelą, którą stanowiła kołdra lub pierzynka, poduszka i perkalikowa kapa. Do kompletu należało dołączyć po 6 prześcieradeł, poszewek na poduszki i nocnych czepków.

Do niezbędnego wyposażenia w 1866 roku należały też farfurki, czyli porcelanowe naczynia w ilości 6 sztuk, sztućce, modlitewnik i pióra do pisania. W kolejnym spisie nie ma wzmianki na temat własnych talerzy, jest zaś konieczność posiadania srebrnej łyżki stołowej, porządnego noża i „grabek”, czyli widelca. Wymagania zmieniły się zapewne pod koniec przedostatniej dekady XIX wieku, dowodzą tego wzmianki w kronice na temat zakupu różnych sprzętów, w tym łóżek oraz naczyń do konwiktu?

Rodzice oddający córkę na pensję musieli liczyć się z jeszcze innymi wydatkami. Opłata za wyżywienie i opał wynosiła 60 florenów, prawie pięć florenów kosztowały książki, papier do pisania oraz świece do oświetlenia pomieszczeń. Wszystkie pensjonarki wnosiły też roczną opłatę za pranie ubrań po 8 florenów i po florenie dla służby szkolnej. Małe dziewczynki miały do pomocy garderobiana, nie wiemy, czy usługa ta była dodatkowo płatna ${ }^{8}$. Ponieważ w szkole przebywała duża liczba pensjonarek i wiele $\mathrm{z}$ nich było na utrzymaniu klasztoru, ich wyposażenie było z pewnością skromniejsze od wymaganego.

Pensjonat wraz ze szkołą znajdował się w obrębie zabudowań klasztornych, w osobnym budynku postawionym w 1823 roku, a rozbudowanym w latach 1885-1888. Stary gmach częściowo rozebrano, przedłużono i dobudowano piętro9 ${ }^{9}$ Umożliwiło to wydzielenie osobnych pomieszczeń na sale szkolne dla każdej klasy, pokoi do nauki dla młodszych i starszych uczennic, sypialni, jadalni, infirmerii oraz dwóch sal rekreacyjnych. Do dyspozycji dziewcząt była też weranda i ogród. Uczennice nie miały możliwości samowolnego opuszczania szkoły, ponieważ przejście wiodło przez strzeżoną furtę, a wyznaczone osoby, czy to guwernantki, czy mistrzynie, miały nad nimi stały nadzór.

Dzień pensjonarki rozpoczynał się dość wcześnie, regulaminy podają godzinę 5.00, 5.30 i 6.00 jako porę wstawania. Nie wiadomo, skąd ta różnica, być może w okresie zimy pozwalano im spać nieco dłużej. Prawdopodobne jest, iż

\footnotetext{
5 ABSt., sygn. 1222.

${ }^{6}$ ABSt., sygn. 1388, s. 21; sygn. 1221, s. 8.

7 ABSt., sygn. 1388, s. 103, 133-134, 174; sygn. 1222.

${ }^{8}$ ABSt., sygn. 1222.

9 B. Krasnowolski, dz. cyt., s. 306.
} 
godzina 6.00 może dotyczyć niedziel i dni świątecznych, gdy nie było w szkole lekcji, Mszę św. odprawiano wtedy o godz. 8.00, a nie tak jak w dni powszednie o 7.00, stąd i możliwość dłuższego odpoczynku. Regulamin z 1880 roku określał, że uczestnictwo w codziennej Mszy św. obowiązuje panny od początku roku szkolnego do rozpoczęcia adwentu i od Wielkanocy do zakończenia roku szkolnego, w pozostałym czasie tylko w niedziele, wtorki i piątki ${ }^{10}$.

Po obudzeniu „mają panny zaraz opuścić łóżeczka swoje, gdyż ociaganie się, powtarzane budzenie uważać by należało za niechęć i opieszałość", a następnie „naznaczyć się znakiem krzyża świętego i pierwszą myśl skierować do Boga, dziękując Mu westchnieniem serdecznem za spokojną noc i szczęśliwe przebudzenie się"11. W ciagu pół godziny należało się ubrać, umyć, pościelić łóżko i być gotowym do wspólnej modlitwy.

Dziewczęta przyzwyczajano do ,prędkiego i schludnego ubierania się z zachowaniem wszelkiej przyzwoitości, skromności i milczenia"12. Do czynności wykonywanych przed pacierzem należało mycie i czesanie. Należało szczególnie młodszym dziewczynkom przypominać o konieczności umycia nie tylko twarzy, ale również uszu, szyi i ust, stanowiło to bardzo ważny element przyzwyczajania ich do zachowania higieny osobistej. Nie zapominano o paznokciach, które miały być obcięte i wyczyszczone, a nie obgryzione, co zapewne zdarzało się wśród pensjonarek, ponieważ uwaga ta została w regulaminie dopisana. Należało też mieć włosy ułożone gładko i skromnie uczesane, obowiązywał zakaz pretensjonalnego kręcenia włosów, noszenia grzywek, wszelkich ozdób, w tym pierścionków i zegarków. Ubrania powinny być pozapinane, dobrze ułożone i całe, „noszenie zaś chustek w niewłaściwym czasie i przy stole daje do sądzenia, że pod niemi nieład w ubieraniu, nieporządek musi być ukryty, przeciwnie daje panienka dowód schludności i dobrego wychowania"13.

Każda panna miała samodzielnie ścielić łóżko „skromnie, ale chędogo”. Uważano to za najlepszy sposób przyzwyczajania się do tzw. zajęć domowych. Wyjątek stanowiły małe dziewczynki, które mogły korzystać z pomocy innych osób ${ }^{14}$.

Milczenie obowiązywało od momentu obudzenia do czasu wspólnego odmówienia pacierza rano oraz po wieczornej modlitwie do zaśnięcia. Zasada ta nie była, jak wynika z zapisek kronikarskich, zawsze przestrzegana. W okresie 12 ostatnich lat urzędowania prefekty Porębskiej nie zachowywano milczenia, a przywrócenie go było niezwykle trudne ze względu na przyzwyczajenia nie tylko starszych uczennic, ale też i guwernantek ${ }^{15}$.

\footnotetext{
${ }^{10}$ ABSt., sygn. 1221, s. 2-3; sygn. 1223, s. 29-30.

11 ABSt., sygn. 1221, s. 2-3.

12 Tamże, s. 3.

13 Tamże, s. 3-4.

14 Tamże, s. 2.

15 ABSt., sygn. 1388, s. 4.
} 
Na poranną Mszę św. wychodzono wspólne, dziewczęta ustawione w pary pod opieką nauczycielki udawały się kościoła. Jeśli któraś z nich miała ,słuszny powód czy to dla słabości, czy dla jakiej innej przyczyny, że nie może iść do kościoła, powinna się pierwej opowiedzieć i usprawiedliwić przed p. mistrzynią, a nie postępować sobie samodzielnie"16.

Najważniejszym elementem wychowania religijnego było przyzwyczajenie uczennic do właściwego zachowania się w kościele. Jeszcze przed wejściem do świątyni dziewczęta miały starać się skoncentrować, a po przestapieniu progu świątyni należało uklęknąć i ,,pochyliwszy się w prawdziwej pokorze głęboko ku ziemi, oddadzą pokłon winny Jezusowi Chrystusowi utajonemu w Przenajświętszym Sakramencie, co powinny czynić zawsze, ile razy koło wielkiego ołtarza przechodzą mówiąc te słowa: Niech będzie pochwalony Przenajświętszy Sakrament" ${ }^{17}$. Każda miała wyznaczone miejsce w ławce, dotyczyło to też uczennic dochodzących do szkoły, których obowiązkiem było punktualne przychodzenie do kościoła. Na początku Mszy św. należało uczynić intencję, a w trakcie modlić się z nabożeństwem, głośno i wyraźnie wymawiać słowa, używając książeczki do nabożeństwa. Dużą rolę przywiązywano też do śpiewu kościelnego, niektóre dziewczęta śpiewały w chórze, inne doraźnie im wtórowały, korzystając ze śpiewników ${ }^{18}$.

Wyjście z kościoła odbywało się w takim samym porządku jak i wejście, następował powrót do pensjonatu, spożywano śniadanie, po nim zabierano przybory szkolne i na znak pierwszego dzwonka, który rozbrzmiewał przed godziną ósmą, pensjonarki udawały się do klas, oczekując tam na drugi dzwonek i osobę prowadzącą lekcje. Przedpołudniowe zajęcia lekcyjne trwały do godziny 11.45, w ich trakcie następowały dwie przerwy. Podczas pierwszej pauzy była dla wszystkich krótka gimnastyka na sali rekreacyjnej, a w trakcie kolejnej konsumowano drugie śniadanie. Młodsze dziewczynki miały zaplanowane półgodzinne ćwiczenia gimnastyczne od 11.45, a starsze po południu o 17.45. Lekcje te stanowiły ważny element zajęć szkolnych, świadczący o zrozumieniu konieczności ruchu dla prawidłowego rozwoju dziecka. Panny ćwiczyły w kostiumach gimnastycznych.

Około godziny 12.30 był obiad, wcześniej należało umyć ręce, ustawić się w pary i dopiero wtedy można było wspólnie udać się do jadalni. Po obiedzie wszystkie panny razem nawiedzały Najświętszy Sakrament i do kolejnych zajęć, rozpoczynających się o godzinie 14.00, była rekreacja. Czas ten poświęcano na zabawę w sali rekreacyjnej, a gdy była ładna pogoda, wychodzono do ogrodu lub na przechadzkę.

Lekcje popołudniowe trwały do 15.45, następnie był podwieczorek i po nim albo realizowano zajęcia nadobowiązkowe, albo czas ten poświęcano na przygotowanie się do lekcji. Około 18.15 przerywano zajęcia, aby wspólne udać się na

\footnotetext{
16 ABSt., sygn. 1221, s. 8.

17 Tamże, s. 6-7.

18 ABSt., sygn. 1221, s. 7-8; sygn. 1223, s. 51.
} 
kolację, a od godz. 19.00 można było ponownie przystąpić do odrabiania lekcji. Po upływie godziny gromadzono się na wieczorny pacierz, następnie młodsze dziewczynki przygotowywały się do snu, a starsze miały możliwość kontynuowania nauki jeszcze do godziny 21.00.

Nieco inny rytm dnia obowiązywał w niedziele i święta. Po Mszy św. odprawionej o godz. 8.00 następowała egzorta wygłaszana przez katechetę w jednej z sal szkolnych. Praktyka taka obowiązywała w 1892 roku, we wcześniejszym okresie egzorta połączona była z popołudniowym nabożeństwem odbywanym o godzinie 15.30. Z tego powodu podwieczorek spożywano pół godziny wcześniej. W niedzielę panny miały też godzinę czasu przed obiadem na napisanie listów, około 14.00 organizowano pogadanki kółek literackich i przyrodniczych, a czas po kolacji przeznaczano na rekreację ${ }^{19}$.

Kształtowanie właściwej postawy religijnej odbywało się poprzez wspomniane już uczestnictwo $\mathrm{w}$ nabożeństwach sprawowanych w kościele, modlitwach oraz przyjmowanie sakramentów. Działaniom tym przyświecała zasada „Kto jest dobrym chrześcijaninem katolikiem, ten jest także dobrym człowiekiem"20. W szkole przygotowywano dziewczynki do przyjęcia Pierwszej Komunii św. i bierzmowania, liczne wzmianki na ten temat zachowały się w kronice konwiktu. Około 1880 roku organizowano spowiedź trzy razy w roku, ale w 1892 roku odbywała się ona już czterokrotnie: na początku i na końcu roku szkolnego, po odbyciu rekolekcji w czasie Wielkiego Postu oraz na św. Scholastykę. Ze względu na dużą liczbę uczennic wyznaczane były dni dla poszczególnych klas, kiedy pod dozorem wyznaczonej osoby wszystkie panny udawały się do spowiedzi. Jeżeli któraś uczennica chciała indywidualnie przystapić do sakramentu pojednania $\mathrm{w}$ innym terminie, mogła to uczynić pod warunkiem poinformowania o tym mistrzyni. Obowiązek przyjmowania Komunii św. dotyczył wszystkich pierwszych piątków miesiąca, w pozostałe dni w ciagu tygodnia zależało to od woli każdej panny. Raz w roku organizowane były rekolekcje, do udziału zobowiązane były wszystkie dziewczęta. Krótkie modlitwy odmawiano codziennie przed i po posiłkach, przed rozpoczęciem lekcji i po ich zakończeniu, a nawet przed rozpoczęciem odrabiania zadanych lekcji. Intencje czynione przed i po lekcjach szkolnych miały być skierowane do Ducha św. o potrzebne łaski i pomoc w nauce ${ }^{21}$.

W regulaminach szkolnych sala lekcyjna wymieniana była jako drugie, najważniejsze po kościele miejsce, dlatego dużo uwagi poświęcono zasadom zachowania się podczas lekcji. Twierdzono, że „dusza odbiera [tam] najdroższy skarb nauk, a serce ukształca się w cnoty, bez których człowiek nie ma wartości" ${ }^{\prime 2}$. Aby uzyskać gruntowne wykształcenie, należało mieć świadomość tego celu i dążyć do jego osiagnięcia ,wszystkiemi siłami woli, serca i umysłu [....] poprzez chwa-

\footnotetext{
${ }^{19}$ ABSt, sygn. 1223, s. 32.

${ }^{20}$ ABSt., sygn. 1223.

${ }^{21}$ ABSt., sygn. 1221, s. 10; sygn. 1222; sygn. 1223, s. 2.

${ }^{22}$ ABSt., sygn. 1223, s. 1.
} 
lebne współzawodnictwo” i „poczytując sobie za punkt honoru wyprzedzanie innych w tej pracy"23. Docenienie wartości nauki przez uczennice oceniane było poprzez skromność w zachowaniu i przestrzeganie przepisów.

Obowiązkiem uczennicy było punktualne uczęszczanie na lekcje, a ewentualne ich opuszczenie możliwe było tylko za wiedzą i zgodą prefekty. Wszystkie książki, zeszyty i przybory potrzebne do lekcji w danym dniu powinny być przygotowane wcześniej, miało to zapobiec poszukiwaniu ich w ostatniej chwili, wędrówkom pomiędzy klasami i sypialniami, a ponadto wyrabiano w ten sposób obowiązkowość. W czasie lekcji wymagano od uczennic maksymalnego skupienia i koncentrowania się na temacie, bo najważniejsze było zrozumienie i zapamiętanie nowych treści. Wszelkie rozmowy, śmiechy, szepty były surowo zakazane. W razie nieprzygotowania można było się usprawiedliwić na początku lekcji, „późniejsze uniewinnienie nie będzie uwzględnione”24. Przyczyną nieprzygotowania mogła być choroba, przyjazd rodziców i inny ważny powód.

Dobrze wychowana uczennica wywołana do odpowiedzi powinna podnieść się cicho z miejsca, stanąć prosto bez pochylania głowy i bawienia się rękoma, odpowiadać głośno i wyraźnie, a na dany znak ponownie zająć swoje miejsce. Jeśli odpowiadała przy tablicy lub mapie, powinna, idąc tam i wracając, ukłonić się nauczycielce. Skromny ukłon pensjonarka powinna uczynić każdorazowo podczas spotkania osoby starszej, zakonnicy i innych ludzi godnych uszanowania. Gdy podczas lekcji do klasy wchodzili goście lub przełożone, uczennice miały obowiązek cichego powstania z miejsc i dopiero na dany znak mogły ponownie je zająć. Niedopuszczalne było chodzenie poklasie podczas lekcji, podchodzenie do stolika nauczycielki bez przywołania, a na wyjście w czasie lekcji musiało być pozwolenie ${ }^{25}$.

Dla zachowania właściwego porządku w klasie książki i zeszyty do czasu nakazania ich położenia na pulpicie miały być schowane, wyjątek stanowiły jedynie atlasy, materiały piśmiennicze, przyrządy geometryczne i materiały do wykonywania robót kobiecych. Wcześniejsze ich wyjmowanie na pulpit uznawano za brak szacunku dla przełożonych. Szczególną uwagę przypisywano samodzielności odpowiedzi, a za wykroczenie uznawano podpowiadanie. Specjalny przepis brzmiał: „Stanowczo zabrania się wszelkich podstępków i podejść przy odpowiedziach, jako to podpowiadania, czy czytywania z książek lekcji, podsuwania książek lub zeszytów, odpisywania zadań, wpisywania thumaczeń do książek, wszystko to bowiem jest wspieraniem opieszałości i sprowadza najgorsze skutki w nauce"26. Jakże aktualny wydaje się ten przepis w dzisiejszych czasach.

W każdej klasie jedna wybrana „wzorowa” uczennica miała odpowiadać za spokój i porządek, w razie potrzeby „grzecznie napominać koleżanki”, a ponadto

23 Tamże.

24 Tamże, s. 12.

25 ABSt., sygn. 1221, s. 27. Wyjście możliwe było „,z ważnych przyczyn, jednak tylko pojedynczo, a nigdy więcej razem".

${ }^{26}$ ABSt., sygn. 1223, s. 58. 
do jej obowiązków należało „zawiadywać dziennikiem klasowym, przygotować do wykładów lub wypracowań atrament, pióra, kredę itp. przybory”, a w razie potrzeby ,jeśli która z osób przełożonych zaciagnąć zechce jakiejś wiadomości, ta tylko odpowiadać ma, aby panny nie przyzwyczajały się do próżnej gadatliwości" ${ }^{27}$. Co tydzień dwie kolejne uczennice pełniły rolę dyżurnych, jedna była odpowiedzialna za porządek w klasie, odmawianie modlitwy i podawanie pomocy naukowych, a druga za przynoszenie map, przyborów oraz wietrzenie klasy. Sumienne wypełnianie zadań skutkowało wysoką notą z porządku i pilności ${ }^{28}$.

Na każdym kroku starano się przyzwyczajać dziewczęta do czystości i porządku, twierdzono, iż od niego zależy zdrowie i zapał do pracy umysłowej. Dlatego, jeśli po lekcjach pozostawały śmiecie na podłodze i ławkach, wszystkie uczennice miały obniżoną ocenę z porządku. Solidarność obowiązywała też przy podwyższaniu oceny, można było ją uzyskać dekorując salę lekcyjną ${ }^{29}$.

Po skończonej lekcji opuszczenie klasy możliwe było tylko wtedy „,dopokąd panna mistrzyni nie da znaku do wyjścia, gdyż cisnąć się około zapisującej do dziennika, zaglądać, co zapisuje a tem bardziej krzyczeć i hałasować jest uchybieniem należytego przełożonym uszanowania i dlatego żadnej bezkarnie ujść to nie powinno" ${ }^{30}$. Wychodzono parami i ,nie wolno pannom odprowadzać nikogo z osób przełożonych przez ganek i kurytarz, ani hałasić, cisnąć się koło niej, bo panny dobrze wychowane powinny się zawsze i wszędzie zachować skromnie"31. Ponadto regulamin zawierał wzmiankę dotyczącą zwracania się do mistrzyń, dziewczęta mogły stosować tylko formę „panna mistrzyni”, używanie wszelkich zdrobnień tłumaczono jako brak szacunku dla przełożonych. Zasada ta wynikała być może z faktu, że uczennice i absolwentki piszące do swoich mistrzyń listy, stosowały pieszczotliwą formę „Pastrzyńciu”, co spotkało się z niechęcią prefekty i ostatecznie zostało wyeliminowane.

Zadane lekcje odrabiano w tak zwanej sali naukowej pod nadzorem wyznaczonej mistrzyni lub guwernantki. Możliwość przebywania w tym pomieszczeniu dotyczyła ściśle wyznaczonych godzin, a jego opuszczenie możliwe było za zgodą osoby pilnującej i tylko na krótki czas. Uczennice po przyjściu na salę miały pięć minut na przygotowanie przyborów i książek, zmówienie pacierza i przystąpienie do odrabiania lekcji. Każda pensjonarka powinna w skupieniu i ciszy pracować nad swoimi lekcjami. W przypadku niezrozumienia tematu lub trudności z wykonaniem zadania należało prosić o pomoc starszą koleżankę, ale „odwodzenie jedna drugą od pilności lub lekceważenie jakiego przedmiotu złą klasę z obyczajów i pilności pociagnie za sobą"32.

\footnotetext{
27 Tamże.

28 Tamże, s. 14-15.

${ }^{29}$ ABSt., sygn. 1221, s. 1.

30 Tamże, s. 31-32.

31 Tamże, s. 31-32.

32 Tamże, s. 10-11.
} 
Nawyków właściwego zachowania się przy stole uczono w jadalni. Na posiłki należało przychodzić punktualnie, a na salę wchodzić w wyznaczonym porządku, spokojnie, nie hałasować i nie rozpychać. Pensjonarka powinna stanąć przy wyznaczonym dla niej miejscu w oczekiwaniu na rozpoczęcie modlitwy i dopiero po jej wspólnym odmówieniu można było usiąść do stołu. Dobrze wychowana panna powinna wystrzegać się siadania bokiem i plecami, trzymania łokci na stole, garbienia się, zwieszania głowy nad talerzem, trzymania sztućców w pięściach i zabawy nimi, robienia niestosownych min oraz pokrzykiwania, aby szybciej podano jedzenie. Dziewczęta były uczone taktownej konsumpcji. Zwracano uwagę, że do spożywania posiłków służyły jedynie łyżka lub widelec i tylko nimi, trzymanymi w prawej ręce, należało podnosić jedzenie do ust. Lewa ręka powinna być w tym czasie wsparta lekko na stole. Za brak wychowania uznawano kruszenie i rozrzucanie chleba, plamienie obrusów czy oblizywanie sztućców. Ganiono też pośpiech i łapczywość podczas jedzenia oraz wpychanie do ust zbyt dużych kęsów. Gdy któraś z dziewcząt nie mogła jeść jakiejś potrawy, powinna o tym poinformować mistrzynię i odstawić talerz. Ale widocznie zdarzały się też inne zachowania, ponieważ jeden z punktów regulaminu brzmiał następująco: ,...grymasy przy stole są bardzo naganne w panience, jeżeli czego nie może jeść powinna poprosić grzecznie o zamianę, ale rzucać talerzami, krzywić się, wygadywać, jest oznaką złego wychowania. Gdy która z panienek znajdzie co w potrawie, włos czy robaczka, nie powinna natenczas ogłaszać wszystkim i obrzydliwość robić innym, ale tylko nieznacznie odsunąć talerz, bo coś podobnego może się zdarzyć wszędzie, w domu i na królewskim stole, gdyż robactwo nie pyta się nikogo o pozwolenie i nie ma na to rozumu, aby innym przykrości nie robić, ale panienka powinna mieć na tyle rozumu, aby wiedzieć, co należy do dobrego wychowania"33. Dopuszczalne było korzystanie z tych samych szklanek w przypadku braku odpowiedniej ich liczby. Jedynym warunkiem było całkowite ich opróżnienie poprzez wypicie wody albo wylanie pozostałego płynu na własny talerz i podanie pustej szklanki następnej pensjonarce.

Podczas obiadu i kolacji czytano książki i inne teksty. W ten sposób w 1890 roku mistrzynie miały zapoznać uczennice z ustawami dla konwiktorek ${ }^{34}$. Dziewczęta musiały słuchać w skupieniu i nie przeszkadzać czytającym nawet najmniejszym szmerem. Wzdłuż stołów jadalnych były ustawione ławki do siedzenia. Zbyt szybkie opuszczenie zajmowanych miejsc przez kilka dziewcząt naraz mogło spowodować wywrócenie się siedziska. Przypadki takie się zdarzały, dlatego do regulaminu wprowadzono zapis o ostrożnym podnoszeniu się z miejsc i podtrzymywaniu ławek podczas wstawania ${ }^{35}$.

33 Tamże, s. 15.

34 ABSt., sygn. 1388, s. 106. W 1892 r. ustawy głośno odczytała aspirantka do klasztoru Sylwestra Niwińska, w obecności dwóch mistrzyń i guwernantki. Por. tamże, s. 165.

${ }^{35}$ ABSt., sygn. 1221, s. 16; sygn. 1223, s. 23-25. 
Dopuszczalne było przysyłanie przez rodziców jedzenia. Należało je oddać do wspólnej szafy, mistrzyni zaś stopniowo udzielała go uczennicy. Jeśli pensjonarka nie zastosowała się do zaleceń i przetrzymywała żywność, rekwirowano ją i rozdawano ubogim ${ }^{36}$.

Miejscem odpoczynku były sypialnie, pensjonarki miały własne łóżka i nocne szafki. W latach 90. XIX wieku każda z nich miała wydzieloną szafę, wcześniej wszystkie rzeczy składały w kufrach i wspólnych szafach stojących na korytarzu. Sobotnie popołudnia były przeznaczone na porządkowanie odzieży, reperację sukien i bielizny. Przebywanie w sypialniach możliwe było jedynie w czasie przeznaczonym na spoczynek. Jeśli któraś z dziewcząt była słaba, niedomagała i potrzebowała odpocząć, po zgłoszeniu tego faktu mistrzyni mogła się położyć. W sypialniach należało się zachowywać cicho, żarty i śmiechy były zabronione, co nie znaczy, że normy te były zawsze przestrzegane. W regulaminie zapisano, że „czas od wieczornego pacierza aż do zaśnięcia obrócą panny z największą korzyścią duszy na dzienne roztrząsanie sumienia. Wszelkich mów i schadzki po wieczornej modlitwie zakazuje się jak najsurowiej, na co panny guwernantki szczególną będą zwracać uwagę”. Zabronione było „także pannom świecić prywatnie przy swoim łóżku, gdyż to przeszkadza innym i może być niebezpieczne" z powodu zaprószenia ognia ${ }^{37}$.

Chore dziewczynki umieszczano w osobnych salach nazywanych infirmerią. Koleżanki mogły odwiedzać chorą tylko za pozwoleniem mistrzyni. W styczniu 1897 roku wybuchła epidemia, najpierw kilka dziewcząt zachorowało na dyfteryt i szkarlatynę, potem 15 przechodziło odrę, a w końcu kolejnych kilkanaście zaczęło się skarżyć na ból gardła, kaszel, chrypkę, niedomaganiom tym towarzyszyła gorączka. I tak chorujące na dyfteryt i szkarlatynę zostały przeniesione do infirmerii na piętrze i oddzielone od pozostałych, dla chorych na odrę wydzielono dwa pomieszczenia, a inne pozostały w swoich pokojach sypialnych. Szczęśliwie wszystkie zostały wykurowane przez siostrę Oskard, bez pomocy lekarza, a „głównem lekarstwem był szlaz z cytryną osłodzony cukrem" ${ }^{38}$.

Czas wolny od wszelkich zajęć lekcyjnych, nabożeństw i posiłków przeznaczano na rekreację, która była uwzględniona w planie każdego dnia. Przestrzegano zasady „w zabawach ma być wesołość i żywotność młodociana, w granicach jednak przyzwoitych" ${ }^{39}$. Te przyzwoite granice oznaczały zasady dobrego wychowania połączone z wzajemną uprzejmością wobec siebie i osób starszych, bez kłótni, krzyków, przezwisk, sprzeczek, zbytnich żartów, wzajemnego popychania się i ,jakiejkolwiek zelżywości”. Zwracano uwagę na właściwe zachowanie, sprzyjające zdrowiu, a przepisy określały, że „na rekreacyach mają się panny wystrzegać wszystkiego, co by ich zdrowiu i sukniom szkodziło, jako to:

\footnotetext{
${ }^{36}$ ABSt., sygn. 1221, s. 12-13.

37 Tamże, s. 33.

38 ABSt., sygn. 1388, s. 373.

${ }^{39}$ ABSt., sygn. 1223, s. 69.
} 
zbytecznego biegania, szamotania się albo pasowania, popychania, uderzania choćby tylko żartem, tarzania się po ziemi, skakania po stołkach lub ławkach, takie igraszki chłopcom ulicznym zostawić należy" ${ }^{40}$. W okresie letnim zalecane były wycieczki na łąkę i do lasu, a od końca lat 80. XIX wieku w kronice zapisywano wzmianki o organizowanych majówkach. Wychodząc poza szkołę, cała grupa ustawiała się w pary i do momentu przejścia przez furtę obowiązywało milczenie, po jej przekroczeniu można było ze sobą rozmawiać, nigdy z osobami napotkanymi, którym należało się jedynie ukłonić i iść dalej. Uczono panny poszanowania przyrody, zwracano uwagę, aby nie deptały pól, nie łamały gałązek i nie niszczyły roślin. Jeśli rekreacja była w ogrodzie, panny powinny się wspólnie bawić i należało je do tego zachęcać. Gdy pogoda była niesprzyjająca, zabawy odbywały się w sali rekreacyjnej, a spacery na werandzie.

Miejscem spotkań z osobami przybywającymi w odwiedziny była rozmównica. O przyjeździe gości powiadamiano mistrzynię i tylko po udzieleniu przez nią zgody starannie uczesana i ubrana w czystą odzież pensjonarka mogła się z nimi spotkać. Prefekta mogła też wyrazić zgodę na przejście do ogrodu i zabranie dziewczynki na przechadzkę, ważne było, aby odwiedziny nie kolidowały z zajęciami w szkole. Kontakty z rodzicami były także utrzymywane poprzez korespondencję. Listy można było wysyłać tylko do rodziców, nie częściej niż co dwa tygodnie, niezaklejone oddawano mistrzyni, która sprawdzała nie tylko wychodząca, ale i przychodzącą korespondencję. Zabronione było proszenie rodziców o przysyłanie jedzenia, a ,listy niedbale i nieporządnie napisane nie moga być wysłane"41. Surowej karze podlegało pisanie i odbieranie liścików za pośrednictwem służących lub gości przybywających do rozmównicy. Z tego powodu papier listowy i znaczki pocztowe każda uczennica musiała zdeponować u przełożonej, podobnie zresztą jak własne książki, gazety, obrazki czy pieniądze ${ }^{42}$.

Te ostatnie przechowywała mistrzyni lub prefekta, aby zapobiec ewentualnym kradzieżom i bezmyślnym wydatkom. W zależności od potrzeb wydzielała pannom stosowne sumy. Obowiązywała zasada, że „fraszek i rzeczy niepotrzebnych kupować nie mają", a najlepiej byłoby kieszonkowe przeznaczyć na książki lub jałmużnę dla ubogich, co byłoby „najsłuszniejsze z chrześcijańskich pobudek, przez wrodzoną dobroć serca i litość nad biednemi"43. Zgodnie z wpajanymi zasadami uczennice za własne pieniądze prenumerowały gazetki „Wieczory rodzinne”, „Mały światek”, a nawet patriotyczną gazetę „Kościuszko”, z oszczędności opłacały fotografa. Otwarte były też na pomoc potrzebującym. Dla poszkodowanych podczas letniej powodzi w 1893 roku mieszkańców Rymanowa

\footnotetext{
${ }^{40}$ ABSt., sygn. 1221, s. 18

41 Tamże, s. 13.

42 ABSt., sygn. 1223, s. 7.

${ }^{43}$ ABSt., sygn. 1221, s. 12.
} 
pensjonarki zebrały pieniądze, bieliznę i odzież, a dzieci w Białej koło Lwowa wspomogły funduszami na budowę polskiej szkoły ${ }^{44}$.

Obowiązywał bezwzględny zakaz pożyczania i korzystania z rzeczy koleżanek bez ich wiedzy i zgody, karą za taki postępek było wydalenie ze szkoły i zła nota $\mathrm{z}$ obyczajów. Każda pensjonarka przybywając do szkoły powinna posiadać rejestr wszystkich przywiezionych rzeczy, które w domu należało oznaczyć w celu ich identyfikacji. Przed oddaniem ubrań do prania jeden wykaz dawano praczce, a według drugiego pensjonarka miała odbierać czyste ubrania ${ }^{45}$.

Do priorytetów wychowawczych należało poszanowanie swojej i cudzej własności. O dobrych nawykach świadczyła dbałość o książki, zarówno kupione przez rodziców, jak i ,udzielone panienkom w ciągu roku do użycia”, oraz estetyczne prowadzenie zeszytów.

Uczennice, które dziurawiły, rysowały lub w jakikolwiek inny sposób niszczyły sprzęty, ponosiły konsekwencje finansowe swoich czynów: „każda z panien, która w czemkolwiek szkodę zrobi, będzie ją musiała z prywatnych pieniędzy nagrodzić, za niedostrzeżonego szkodnika cały pokój, sala lub klasa odpowie"46. Kara wynosiła czterokrotną wartość szkody, z czego jedna część była na jej usunięcie, a pozostałą przeznaczano na jałmużnę ${ }^{47}$.

Ukształtowanie właściwej postawy dokonywało się też poprzez stosunek do drugiego człowieka. Panny uczone były wszelkich form grzecznościowych, szacunku wobec starszych, krótkich i śmiałych odpowiedzi na pytania, a zasłanianie ust i oczu podczas rozmowy, śmianie się i strojenie min było ganione. Przepisy zabraniały całowania w rękę osób starszych ,bez przyczyny i w nieodpowiednim czasie", dopuszczano jedynie taką możliwość w przypadku wyjazdu i przyjazdu uczennicy oraz podczas przeprosin, kiedy panna obraziła którąś z osób przełożonych ${ }^{48}$. Sytuacje takie z pewnością się zdarzały, bo stosowne przepisy mówiły, że wszelkie przestrogi, napominania i nauki „mają panny przyjmować uprzejmie i z wdzięcznością", a nieposłuszeństwo karane było wpisem do dziennika i niską oceną z obyczajów. Gdyby jednak w klasach dochodziło do ,złości, uporu każdego i z nieuszanowaniem odpowiadania, zacięcia się, krnąbrności, kiwania głową, a co jeszcze gorsza zmawiania się, spisków, poduszczania innych i niejako niby buntów, tu się strzec potrzeba, bo te jako największe w młodym wieku występki muszą być karane wydaleniem" z pensji ${ }^{49}$.

Zabronione było spoufalanie się uczennic ze służbą, złe ich traktowanie czy obrażanie. Jeśli konieczna była ich pomoc, należało o nią grzecznie poprosić i podziękować za przysługę. Brak szacunku do służby uznawano za „dowód złego

\footnotetext{
${ }^{44}$ ABSt., sygn. 1388, s. 183-184, 190-191, 231, 235, 343

45 ABSt., sygn. 1221, 22-23, 31.

46 Tamże, s. 22.

47 ABSt., sygn. 1223, s. 8.

48 ABSt., sygn 1221, s. 18-19.

49 Tamże, s. 28-29.
} 
i okrutnego serca" ${ }^{50}$. Zachęcano do wynagradzania ich datkami przy wyjeździe na wakacje $\mathrm{e}^{51}$.

Przepisy regulowały też wzajemne relacje i stosunki między uczennicami w zakresie odnoszenia się do siebie. Podstawową zasadą było koleżeństwo, przyjaźń, grzeczne i uprzejme traktowanie się nawzajem i ,starsze panny młodszem dobrym przykładem przyświecać powinny". Zwracano uwagę na właściwe odnoszenie się do siebie, a „wszelkie przezwiska przyswojone w domu, przekręcanie imion, wyśmiewanie się z mowy, nazwisk innych, naśmiewanie się z ułożenia, wad lub obmowy, okazywałyby brak rozsądku i wychowania oraz niedobre serce a przeto są surowo zakazane"s2.

Za najważniejsze w wychowaniu uznawano kształtowanie nienagannej moralności dziewcząt, $\mathrm{w}$ regulaminie zapisano, iż wszelkie wykroczenia przeciw temu groziły wydaleniem z pensji: „Panny, któreby się ważyły mówić przeciwko skromności i czegoby się wstydziły powtórzyć przy starszych [...] będą karane [...], równie i te nie znajdą przebaczenia, któreby się odważyły złych mów słuchać i o tych nie donosiły swoim przełożonym, które ze zgorszeniem złe mowy prowadziły" ${ }^{53}$. Aby temu zapobiec, należało pilnować, szczególnie podczas rekreacji, ,żeby nie chodziły zawsze jedna z tą samą, żeby w sekrecie jedna od drugiej żadnych zwierzeń nie przyjmowała. Nie wolno między sobą szeptać i wyrażać się dwuznacznie" "54. W kronice odnotowano konieczność opuszczenia szkoły przez zaręczoną uczennice, a dwie inne usunięto za opowiadanie „niestosownych rzeczy", zły, a wręcz gorszący wpływ na koleżanki ${ }^{55}$.

Dyscyplina obowiązywała też w kwestii terminowych przyjazdów na pensję. Jedna z pensjonarek ,za dobrowolne i lekkomyślne opóźnienie się z przyjazdem do konwiktu po świętach Bożego Narodzenia" została wyrzucona ze szkoły. Jednak ,najważniejszą przyczyną były bale po kasynach, z któremi jawnie pochwaliła się, pisząc do swoich koleżanek, obiecując im za przyjazdem różne rzeczy opowiadać" 56 .

Rok szkolny trwał od września do lipca, podczas wakacji wyjeżdżano do domów, chociaż niektóre dziewczęta pozostawały w pensjonacie. Wyjazdy możliwe były na święta Bożego Narodzenia i Wielkanoc, ale prefekta mogła zabronić tego pannom niegrzecznym i słabo przykładającym się do nauki. Podczas Bożego Narodzenia w 1895 roku po raz pierwszy urządzono dla tych uczennic, które nie wyjeżdżały na święta do domu, choinkę, a pod nią szopkę. Dniami wolnymi

50 Tamże, s. 21.

${ }^{51}$ ABSt., sygn. 1223, z. 73. „Przyjętym jest ogólnie zwyczaj wynagradzania małym datkiem służby za ich posługi, o czem panny przy opuszczaniu klasztoru na końcu roku szkolnego nie zapomną. Nie jest to obowiązkiem, ale dowodem pamięci i ciężkiej pracy fizycznej”.

${ }^{52}$ ABSt., sygn. 1221, s. 20.

53 Tamże, s. 21.

54 Tamże.

55 ABSt., sygn. 1388, s. 308-309, 322-323.

56 Tamże, s. 283. 
od lekcji, oprócz niedziel i świąt, były dzień imienin monarchy, ksieni, prefekty i katechety ${ }^{57}$.

Realizowane w szkole lekcje dzieliły się na obowiązkowe, wynikające z programu szkoły, oraz nadobowiązkowe, do których należały lekcje tańca, gry na instrumentach muzycznych, przede wszystkim na fortepianie. Podstawą zdobycia umiejętności gry było systematyczne ćwiczenie, co szczególnie mocno podkreślano pisząc, iż ,godziny fortepianu żadnych wakacyi mieć nie powinny” i dlatego ,godzin przeznaczonych na fortepian same panny powinny pilnować, któraby się w tym względzie zapomniała, będzie jej to za opieszałość do nauk poczytane i karane złą klasą"58. Nakazana była też konwersacja w języku francuskim i niemieckim w celu nabrania biegłości w sprawnym mówieniu ${ }^{59}$.

Do stałych elementów życia pensjonarek należały spektakle teatralne, przygotowywane z dużym rozmachem i mające ogromną wartość edukacyjną. Fundusze na dekoracje i stroje uzyskiwano podczas organizowanych przez uczennice loterii fantowych ${ }^{60}$.

Reasumując należy stwierdzić, że precyzyjnie określone przepisy i wymagania, przyzwyczajanie do systematyczności, porządku, obowiązkowości, zorganizowanie zajęć i wypełnianie nimi całego dnia uczennicy, połączenie nauki, modlitwy i odpoczynku, kształtowanie w duchu ,religijno-moralnym charakterów" to główne przesłanki funkcjonowania szkoły staniąteckiej w 2. połowie XIX wieku.

\section{From the history of the female school in Staniątki in the second half of the XIX century (Summary)}

The convent school for girls had been managed by Benedictines in Staniątki at least since XVI century. After the inclusion into the Austrian annexation in 1784 the transformation of the school from convent into so-called "normal" followed and it was subordinated to secular authorities organizationally and programmatically. The existence of nunnery was depended on the acceptance of school that functioned at it. The situation changed after the introduction of the autonomy in Galicia, then in 1869 the school obtained the status of the private female school, acknowledged equally with schools that had public laws. This was the boarding-school for girls and rules of functioning were qualified by internal regulations some of them remained in monastic archives. The most important aim was the education according to the religious-moral spirit and complete schooling,

57 Tamże, s. 364; sygn. 1223, s. 69.

58 ABSt., sygn. 1221, s. 5.

59 Tamże, s. 23. „W wolnych chwilach przy obiedzie, kolacyi, na salach i rekreacyach, w klasach i wszędzie mają panny mówić po francusku i niemiecku".

${ }^{60}$ ABSt., sygn. 1388, s. 15-17, 139. 
which gives bases to the further education. Regulations in detail defined requirements to schoolgirls among which there was accustoming of girls to the regularity in working, the order, the sense of duty, the obedience in the face of superiors, the respect in the face of themselves and the others. The limits of behaving were clearly defined and fulfilling of duties was executed meticulously. The breaking of obligatory regulations threatened with the punishment and the expulsion from the school. The schoolgirl's day was organised so, that all the time it was filled with the education, the prayer and the rest. The unusual attention was paid on the hygiene of the mental work, girls' health and development and the proper formation of the character, in accordance with the accepted educational ideals. 